\title{
BEM VIVER E PROPRIEDADE: O PROBLEMA DA DIFERENCIAÇÃO ENTRE OS XIKRIN-MEBÊNGÔKRE (KAYAPÓ) *
}

Cesar Gordon

\section{Prólogo}

Nas sociedades ocidentais contemporâneas, a relação entre bem viver e propriedade é muitas vezes tida como autoevidente. Parece não haver grandes discordâncias nas concepções correntes sobre sociedade e economia de que o bem viver depende fundamentalmente de certos tipos de propriedade ou, em última instância, de determinados padrões mínimos de renda que garantiriam a propriedade de bens tidos como fundamentais (Knight 1971; Canto 1985; Norton 1998; Frey 2002). A expansão quase ilimitada e global do consumo parece ser o resultado lógico e a realização prática dessa premissa. Não apenas o bem viver, mas também a própria felicidade e a dignidade humana são vistas como dependentes da propriedade de um conjunto de bens que garantiriam a autonomia econômica, ajudando a constituir as pessoas e as subjetividades em nossas sociedades de consumo (Miller 1987). Mas quando voltamos os olhos para o mundo indígena, especificamente na direção das sociedades indígenas das terras baixas sul-americanas, o que ocorre com essa equação? É possível detectar ali noções equivalentes ou análogas às de propriedade e bem viver? E se a resposta for positiva, de que maneira essas noções, ou suas equivalentes, poderiam estar articuladas na imaginação conceitual, moral e nas práticas indígenas?

Estas são questões complexas e difíceis, e não serão certamente resolvidas aqui. O presente artigo é apenas uma primeira tentativa de refletir sobre propriedade e bem viver em um contexto etnográfico específico, a saber, aquele dos Xikrin do Cateté, grupo Mebêngôkre (Kayapó), da Amazônia brasileira. Na primeira parte do artigo, dedico-me a esclarecer o uso que faço da noção um tanto vaga de "bem viver" desde o ponto de vista da etnografia mebêngôkre. Sugiro que ela pode ser expressa por um conceito que carrega, ao mesmo tempo, dimensões éticas e estéticas: o conceito de belo ou bom (mejx), termo que já foi descrito por diferentes etnógrafos (Turner 
1984; Lea 1986, 2012), e do qual eu mesmo já tratei em outra ocasião (Gordon 2011), mas que julgo oportuno retomar aqui, juntamente com outras noções, igualmente presentes nas formulações xikrin relacionadas ao bem viver, como, por exemplo, vergonha ou respeito (pia'àm) e entendimento (kuma). Pretendo sustentar que noções de bem viver devem ser articuladas com um problema indígena filosófico e existencial de magnitude, a saber, a questão da diferenciação. Colocado de maneira brusca, e como argumento polêmico a defender no restante do artigo, eu diria que uma das definições do viver bem no mundo social mebêngôkre é manter, em todos os níveis da vida social, um determinado quociente de diferenciação, ou ainda, o que é a mesma coisa, não cair em um estado geral de indiferenciação.

Na segunda parte, tento relacionar esta formulação com a ideia de propriedade, ou de algo que, no contexto social xikrin-mebêngôkre, guarde analogia ou funcione como equivalente da noção de propriedade. ${ }^{1}$ Sugiro que, no caso mebêngôkre, a tarefa de encontrar conceito equivalente à propriedade é de algum modo facilitada. Isto porque sabemos da existência de um conjunto de prerrogativas rituais, expresso pelos termos nekrêjx ou kukràdjà, que faz parte de acervos familiares e pessoais, como muito bem descreveu Vanessa Lea $(1986,2012)$, autora que considerou pela primeira vez tais bens como um tipo de "riqueza" da sociedade kayapó. A hipótese a ser avançada é que bem viver está associado com o problema da diferenciação, e que esta, por sua vez, em um plano sociológico geral, vincula-se à questão da propriedade (especificamente quando se trata da propriedade cerimonial), uma vez que podemos entender o sistema ritual como o mecanismo básico, em nível coletivo, de diferenciação na sociedade mebêngôkre. Assim, o estabelecimento de um sistema de repartição de propriedade, de tipo totêmico, seria um importante mecanismo para evitar crises de indiferenciação e, portanto, garantir o bem viver.

Por fim, na última parte, à guisa de conclusão, sugiro que o sistema ritual mebêngôkre passou por mudanças importantes que, de certa maneira, deslocaram um tipo de diferenciação totêmica equiestatutária na direção de um tipo de diferenciação mais marcadamente hierárquica, na qual há margem para o desenvolvimento de relações rivalitárias no interior das comunidades e entre elas. Este último tipo de diferenciação já foi descrito e analisado pelos antropólogos que estudaram os grupos mebêngôkre, e pode ser expresso pela oposição nativa entre "belos" ou donos de nomes e prerrogativas rituais (me mejx) versus "comuns" ou desprovidos de bens cerimoniais de valor (me kakrit) (cf Turner 1984; Lea 1986; Verswijver 1992). Essa mudança parece resultar naquilo que estou chamando de crise ritual, a saber, um processo cismogenético (Bateson 1958) de aceleração das di- 
nâmicas rivalitárias, e de incapacidade crescente de diferenciação, levando todo o sistema a um viés cada vez mais centrífugo, nos termos de Fausto (2001), e marcado por um caráter agonístico, expresso pelo que os etnógrafos chamaram de "faccionalismo" mebêngôkre.

\section{Bem viver e o problema da diferenciação entre os Mebêngôkre}

Antes de passar à analise do material etnográfico, e sem qualquer pretensão de traçar uma genealogia do conceito de bem viver (ou wellbeing) na antropologia de maneira geral, ${ }^{2}$ cabe um breve comentário que nos ajude a situar o problema desde a perspectiva da etnologia indígena amazônica. Luisa Elvira Belaúnde (2001), por exemplo, explorou de forma interessante a centralidade das noções de "buena vida" e "vivir bien" na constituição comunitária dos índios Airo Pai, falantes de língua tukano ocidental, habitantes do norte do Peru. Mais recentemente, Vanessa Grotti (2007) abordou o conceito de wellbeing em trabalho sobre os Trio e os Wayana da Guiana. A autora demonstra que o conceito se situa no campo de um conjunto de fenômenos e discursos indígenas já tematizados por diversos etnólogos americanistas, cujas análises foram classificadas por Eduardo Viveiros de Castro (1996) sob o rótulo de "economia moral da intimidade". De fato, a noção de bem viver tem forte ressonância com a ideia de "convivialidade", tal como aparece mais claramente formulada por Joanna Overing, em especial na coletânea organizada junto com Alan Passes (Overing \& Passes 2000).

Rejeitando as chamadas "grandes narrativas modernistas sobre a sociedade" (2000:1), Overing e Passes sugerem que o mundo indígena amazônico deve ser compreendido a partir do idioma da convivialidade, o qual, segundo eles, "define um modo de socialidade amazônico" (2000:xiii). A convivialidade amazônica consiste, para os autores, em elementos que podem ser encontrados na tradição ocidental cristã tomista (amizade, liberdade nas relações pessoais, ausência de coerção, igualitarismo), somados a elementos mais propriamente nativos (mas que certamente se encontram também em variantes do romantismo ocidental), como a busca por tranquilidade, "moral alta, afetividade desenvolvida, uma metafísica da conexão entre humanos e não humanos, ênfase no parentesco, na partilha e na dádiva [...] uma propensão para a informalidade [...] e uma intensa valorização ética e estética da sociabilidade" (2000:xiii-xiv).

Assim, poderíamos concluir que, na Amazônia indígena, a condição de viver bem estaria relacionada a uma estética e a uma moralidade que valorizam os sentimentos de pertença, as relações de cuidado cotidiano 
entre parentes, os afetos familiares, a comensalidade, a partilha, a dádiva, a afabilidade, o suporte emocional, a compaixão e a liberdade pessoal. Uma estética e uma ética estreitamente associadas ao fluxo da vida cotidiana e ao universo do parentesco próximo e da convivência íntima do grupo de cognatos.

Um dos argumentos centrais de Overing e Passes consiste em opor este estado de convivialidade a uma visão "jural" ou "estrutural" do mundo amazônico. Segundo os autores, os povos indígenas estariam pouco preocupados com o aspecto formal ou institucional da vida social, tendo pouco a dizer sobre papéis, status, grupos corporados ou hierarquias (2000:2). Eles estariam mais propensos a buscar uma vida feliz e psicologicamente confortável a partir da convivência cotidiana do que em "construir estruturas sociais" (2000). Nesse sentido, fica clara a crítica de Overing e Passes a uma antropologia "convencional", por assim dizer, seja em sua versão funcionalista ou estruturalista. É como se o pensamento sociológico e o estruturalista não estivessem aptos a compreender a sociabilidade ameríndia, uma vez que esta não se pauta pela formação de estruturas societárias, e sim pela constituição de um universo social mais ou menos indiferenciado, "liso", igualitário, uniforme, baseado na estética e na ética da convivialidade. Overing e Passes apontam, além disso, para uma suposta incompatibilidade entre o desejo de viver bem e os mecanismos de estruturação e diferenciação social.

Nos limites deste artigo eu não pretendo discutir em todos os detalhes o mérito do modelo de Overing e Passes, bem como sua dependência a uma tradição de pensamento ocidental tão antiga quanto as "grandes narrativas modernas", ainda que remodelada pelas influências new age e pós-modernas; nem tampouco sua inaplicabilidade a vastas áreas etnográficas amazônicas, como o Alto Xingu (Franchetto \& Heckeberger 2001), o Brasil Central (Maybury-Lewis 1979), o Noroeste Amazônico (Hugh-Jones 1993; Lasmar 2002), por exemplo. ${ }^{3}$ O modelo não parece generalizável quando saímos de comunidades pequenas, atomizadas, territorialmente dispersas para um cenário de unidades sociológicas maiores, territorialmente mais estabilizadas, onde há, por exemplo, grandes aldeias com população maior que mil habitantes. De maneira mais particular, todavia, quero sugerir que se tomamos a ideia de vida boa e correta no sentido que, penso eu, lhes dão os Xikrin, as proposições de Overing e Passes não são plenamente sustentáveis. Muito pelo contrário, uma análise do material etnográfico mebêngôkre permite inferir que, exatamente ao contrário do que afirmam aqueles autores, não há qualquer incompatibilidade entre o desejo de viver bem e os mecanismos sociológicos ("estruturais") de diferenciação social, pois estes últimos são a condição de possibilidade do primeiro. 
Os Xikrin são cerca de 900 pessoas que habitam a região da bacia do rio Itacaiúnas, no sudeste do Pará, Brasil. São um dos grupos falantes de língua mebêngôkre (ou kayapó setentrional), pertencente à família linguística jê. Eles compartilham com os demais Mebêngôkre, além da língua, uma mesma origem histórica e um conjunto de características socioculturais bem conhecidas na literatura etnográfica (cf., por exemplo, Turner 1966; Vidal 1977; Lea 1986; Verswijver 1992). Tomados em conjunto, os Mebêngôkre somam hoje aproximadamente 10 mil índios vivendo em diversas aldeias, em um amplo território nos estados do Pará e Mato Grosso. Cada aldeia constitui um universo político e territorial relativamente autônomo, mas há entre elas profundas conexões de várias ordens (linguísticas, históricas e socioculturais) que indicam a necessidade de pensá-las, não isoladamente, porém compondo um único regime relacional mebêngôkre. ${ }^{4}$

O que podemos dizer das ideias de bem viver entre os Xikrin e Mebêngôkre afinal? A princípio, aparentemente contrariando o que acabo de dizer, o discurso dos Xikrin sobre o que é ou deveria ser uma boa vida apresenta uma série de elementos comuns aos de outros povos indígenas (e não indígenas), evocando as figuras da socialidade amazônica desenhadas por Overing e Passes. Aqui também, como em qualquer lugar, enfatiza-se a importância da harmonia e da paz no interior das aldeias e entre as diferentes aldeias mebêngôkre como um fator para o bem-estar. Os Xikrin costumam dizer que viver bem é viver sem brigas, sem violência, com fartura, sem doenças, fazendo muitas festas grandes, contando com a participação de todos, enfim, em uma situação harmônica, equilibrada e estruturada que agrada e deixa as pessoas felizes (me mã kinh, kam me kuni kinh). Na situação de insularidade dentro do Estado nacional brasileiro, viver bem também está relacionado à autonomia comunitária e a uma certa segurança jurídico-institucional, que envolve a demarcação e a proteção do território indígena, mínimo controle sobre os processos políticos decisórios que afetam a vida na aldeia, entre outros. Porém, essas apreciações iniciais, muito gerais, apenas aparentemente ecoam a visão projetada por Overing e Passes. Na realidade, elas não esgotam o problema e não delimitam completamente o campo do "bem viver" entre os Xikrin. É preciso, portanto, analisar mais detidamente os dados etnográficos, enfocando a questão a partir de algumas categorias-chave pelas quais os Xikrin a expressam.

Não existindo um termo específico para exprimi-las, as noções de bem viver para os Xikrin são normalmente verbalizadas pelo uso da palavra mebêngôkre mejx, como nas expressões kam mejx, mejx o ari ba, mejx kumrenx, com o significado próximo de "ficar bem", "estar bem", "muito bom/bem", respectivamente. O campo semântico desta palavra recobre uma série de 
atributos que poderíamos traduzir por "bom, bem, belo, bonito, correto, perfeito, ótimo". A palavra tem larguíssimo uso no discurso indígena cotidiano, qualificando desde coisas físicas (objetos e corpos) a coisas mais abstratas (nomes, pessoas, situações), e exprimindo tanto valores estéticos quanto éticos e morais. Em síntese, mejx designa valores essenciais para os Xikrin. Produzir ou obter coisas, pessoas, comunidades e, enfim, uma vida mejx parece ser a finalidade última da ação xikrin, manifestando-se nas esferas individual e coletiva. Um ponto importante a observar, e eu voltarei a isto adiante, é que a obtenção (individual ou coletiva) desta qualidade ou deste estado mejx está, em certo plano, intrinsecamente relacionada ao domínio ritual, e depende de maneira fundamental da propriedade e do controle sobre determinados objetos e direitos cerimoniais, dentre os quais nomes, adornos, papéis rituais e prerrogativas.

Em outro trabalho, analisei mais detidamente o conceito de mejx entre os Xikrin, procurando discernir seus atributos, tanto no que diz respeito à sua aplicação a objetos e pessoas quanto a seu componente mais imaterial, por assim dizer, em que ressalta sua vinculação aos domínios sociológicos e cosmológicos (Gordon 2011). Sem retomar os detalhes do argumento, gostaria de destacar um elemento formal fundamental para a definição xikrin de mejx. É que, replicados em planos e níveis diferentes, notamos a presença dos mesmos princípios ou critérios de reconhecimento da beleza e da correção, assim como um belo objeto (um adorno, por exemplo), um belo corpo e uma bela festa são, igualmente, o resultado harmônico da produção de alinhamentos e separações, aproximações e afastamentos diferenciais dos elementos que compõem a unidade em questão, uns em relação aos outros (Gordon 2011:221).

O ordenamento e a estruturação espaço-temporal dos bens cerimoniais que compõem uma determinada ação ou fase ritual, por exemplo, são fatores constitutivos da beleza da cerimônia, da mesma forma que a sequência, a ordem e o espaçamento entre diferentes conjuntos de plumas podem ser fatores constitutivos da beleza e da correção de um cocar. O paralelismo formal estende-se à constituição das próprias pessoas, uma vez que sua beleza depende do agenciamento diferencial de relações sociais distintas, isto é, da ação diferencial, em diferentes etapas do ciclo de vida da pessoa, de determinados parentes, como os pais (genitores), os pais classificatórios ou putativos, os parentes cruzados - tios maternos ou avós (nominadores) - e os amigos formais (relação especial, que já foi considerada nas etnografias como uma espécie de relação de compadrio).

Desta forma, implícita à noção xikrin do belo e do bom parece haver uma determinada ideia de diferenciação. O belo, em seus vários planos de 
realização, depende da diferença ou, em outras palavras, de uma certa estruturação posicional de elementos diferenciais. E se minha análise procede, é notável o paralelismo destas concepções xikrin com os modelos da linguística e da antropologia estrutural de matriz saussuriana e lévi-straussiana.

Todavia, se isto nos esclarece acerca do sentido da categoria mejx, nada nos diz diretamente sobre as concepções do bem viver, que são geralmente expressas por aquele termo. Para tentar demonstrar mais claramente a conexão, precisaremos nos acercar das concepções do bem viver indiretamente, por meio do exame do seu contrário. Podemos nos perguntar, por exemplo, o que representaria uma vida "ruim" (punure) em contraste com o bem viver. É precisamente aí, penso eu, que a questão da diferenciação reaparece de forma muito significativa. Vejamos como.

Do que posso extrair dos discursos de uma parte dos Xikrin com quem convivi mais proximamente, haveria, segundo eles, um conjunto de elementos negativos, destrutivos e limitadores do bem viver. Em primeiro lugar, seguramente, a violência. A violência pode ser uma força exterior, que aparece de maneira imprevisível, como nos casos de ataques e agressões cometidos contra eles por inimigos. Felizmente, dizem os Xikrin, essa é uma dimensão que pertence cada vez mais ao passado, haja vista que, desde os contatos permanentes com a sociedade brasileira, as relações com os estrangeiros, indígenas ou não, vêm se desenvolvendo quase sempre em uma chave pacífica. Mas há também a possibilidade de um outro tipo de violência, que muito os preocupa: a violência interna, surgida das tensões no seio da comunidade.

De fato, uma das características reconhecidas nos grupos mebêngôkre é aquilo que alguns antropólogos apontaram como seu pronunciado "faccionalismo" (Bamberger 1979). Desde os primeiros relatos acerca desses índios, ainda no século XIX, as dissensões internas, os conflitos e as disputas faccionais, as divisões violentas das comunidades, as inimizades e os ódios fratricidas foram uma constante. Os Mebêngôkre viveram períodos de intensas rivalidades que, em geral, começaram no interior das aldeias, causaram cisões, e se perpetuaram em guerras intercomunitárias (Turner 1966; Vidal 1977; Verswjiver 1992; Fisher 2000). Entre meados do século XIX e início do XX, até o período imediatamente anterior ao processo de "pacificação" por órgãos do Estado brasileiro, que ocorreu na década de 1950, diversos grupos mebêngôkre experimentaram guerras do tipo blood feud.

No início do século passado, por exemplo, os Kayapó Mekrãnotire separaram-se dos Kayapó Gorotire e, a partir daí, os dois grupos passaram por uma sequência de cismas internos (Verswjiver 1992). Por volta dos anos 1910, iniciaram-se também os conflitos entre os Xikrin e os Kayapó Gorotire, 
conflitos que se estenderam por décadas, causando inúmeras mortes de ambos os lados. Em seguida, ocorreu um processo semelhante, porém no seio da própria comunidade Xikrin, resultando na separação do grupo do Bacajá (que foi habitar as margens do rio Bacajá, próximo ao que é hoje o município de Altamira) do grupo do Cateté (Vidal 1977; Fisher 2000). Neste último grupo, fortes rivalidades entre pai e filho pelo comando da aldeia resultaram em uma cisão em 1962. Mais recentemente, a rivalidade entre dois irmãos, filhos do velho chefe, e posteriormente entre os filhos dos filhos (que também disputavam prestígio e a liderança da comunidade) resultou em nova cisão da aldeia do Cateté em 1993 (Gordon 2006:163). ${ }^{5}$

No passado, os Mebêngôkre chegaram a elaborar um mecanismo ritual para tentar resolver os conflitos internos, que funcionava quase como instrumento proto-jurídico, como foi o caso do duelo coletivo formalizado denominado aben tak ("baterem-se uns contra os outros"), em que os derrotados reconheciam a superioridade dos vencedores, encerrando as queixas (Turner 1966). No entanto, conforme registram as etnografias, esse instrumento nem sempre era eficaz, muitas vezes provocando o efeito contrário de acirramento das tensões, e funcionando como combustível do conflito (Turner 1996; Verswjiver 1992). Hoje, cisões continuam a ocorrer, como testemunha a proliferação sempre crescente de novas aldeias, ainda que os conflitos violentos tenham diminuído consideravelmente, substituídos por soluções que assumem um caráter mais político do que belicoso. Mas o espectro dessa violência interna continua vivo. Ela não mais atinge necessariamente a comunidade por inteiro, mas pode manifestar-se em termos de relações individualizadas e pessoais.

Tradicionalmente, as disputas internas giravam em torno de acusações de feitiçaria, relações extraconjugais, roubos, disputas por direitos e prerrogativas, ou ainda por quaisquer outros eventos de forte carga emocional, uma vez que eles fomentavam ressentimentos e desejos de vingança. Muito embora o "ethos" guerreiro e a belicosidade - expressos pelo termo àkrê seja um valor entre os Mebêngôkre (Verswjiver 1992), sua positividade situa-se primordialmente no plano das relações com o universo social externo ao domínio comunitário aldeão, posto que neste último deve imperar a lógica da domesticidade, qualidade simétrica e complementar à belicosidade, e que é designada pelo termo uabô (Gordon s/d).

Em todo caso, invariavelmente, os conflitos são entendidos pelos Xikrin como efeito de fatores tais como a avareza (õ djö), o ciúme e a inveja (djàpnhin) e as rivalidades (aben o kurê, aben mã àkrê, isto é, "odiar-se mutuamente", "ser tomado de ira mútua"). Tanto a avareza quanto o ciúme e a inveja podem ser pensados como fenômenos resultantes de processos de indiferenciação, 
no sentido de instaurarem uma relação de tipo mimético (Girard 1972) entre os envolvidos, fazendo desaparecer a distância que garantia a complementaridade entre os termos. Sem a distância, os termos passam a se chocar uns com os outros na disputa pela mesma posição, substituindo assim a complementaridade pela rivalidade, à semelhança das narrativas dos gêmeos Sol (myt) e Lua (myturwa). No mito, a separação de sol e lua garante o equilíbrio cósmico, ao passo que seu encontro acarreta rivalidades miméticas cujo resultado é violência, luta ou assassinato (Lukesch 1976:27-33). A redução da distância entre os astros simboliza o processo de indiferenciação instaurado pelo mimetismo de apropriação: passa-se a desejar as mesmas coisas que o outro; passa-se a desejar ocupar o lugar do outro. E a perda da diferença leva a uma espécie de relação especular, com emergência de duplos idênticos. Talvez seja por esta razão que a gemelaridade possui conotações negativas entre os Xikrin. Para eles, os gêmeos idênticos são sinais de mau agouro, associados a animais como cachorro, cobra e larvas de inseto. ${ }^{6}$

Diferença e distância são, portanto, correlativas. Neste ponto, devemos entrar em considerações sobre o bem viver, que se articulam com outro conjunto de categorias cruciais, notadamente as noções que implicam distância, como "vergonha", "respeito", "juízo" e "entendimento". De fato, é consenso entre os Xikrin que não se pode viver bem quando não há o devido respeito e não se cumprem as regras mínimas de convivência social, expressas pelo termo pia'àm. A palavra, normalmente glosada por "vergonha" ou "respeito", tem uma importância fundamental na socialidade mebêngôkre, definindo o que é próprio das relações sociais entre humanos e sendo o operador por excelência de distância social (veja-se a boa análise comparativa de Coelho de Souza 2002:497-513).

A ausência de pia'àm é a marca inconfundível da indiferenciação, característica de um mundo social bestial, onde não se distinguem as relações de parentesco, onde tudo é misturado e confuso, como em um bando de porcos do mato ou em uma matilha de cães. No universo mebêngôkre, vale o que Coelho de Souza descreveu também para os outros Jê setentrionais: "Todas as relações caracterizadas por uma diferença, sexual, geracional ou etária seriam assim, em alguma medida, marcadas por piâm [...]" (Coelho de Souza 2002:500, ênfase minha). A distância é fundamental, tanto no plano das relações de pessoa a pessoa, quanto nas relações entre grupos ou unidades coletivas, como associações masculinas. ${ }^{7}$ Note-se en passant que quando os Xikrin tecem avaliações morais negativas a respeito dos brancos, ou de estrangeiros em geral, costumam destacar que seu caráter monstruoso deriva, em boa parte, da falta de vergonha.

A falta de vergonha e de respeito também está associada a uma dimensão dramática da indiferenciação: o problema do incesto. Os Xikrin, 
até onde pude saber, não costumam falar regularmente (ou abertamente) de incesto. Também não há no corpus narrativo mebêngôkre uma profusão de mitos sobre este tema, ainda que haja alguns significativos. No entanto, as referências míticas permitem sugerir que o incesto é pensado como um retorno à indiferenciação não humana e bestial (Wilbert 1978). Os mitos que falam de incesto contam como os incestuosos transformam-se em animais inclusive animais considerados como a própria peste ou veículo de morte (caso das garças), e provocam cataclismos cósmicos (Lukesch 1976). Alguns informantes associaram o incesto ao nascimento de gêmeos, o que parece fazer muito sentido, se levarmos em conta as observações que tecemos acima.

A vergonha e o respeito associam-se complementarmente à noção mais positiva de "entendimento" ou de "compreensão", expressa pelo verbo mebêngôkre ma (ou mari). O verbo ma denota qualidades físicas e mentais ou morais, podendo ser traduzido por ouvir, escutar, atender, entender, lembrar, pensar. A palavra kuma, composta pelo verbo flexionado no acusativo $(k u)$, designa a faculdade de pensar racionalmente ou reflexivamente, de modo a seguir os preceitos ditados pelo pia'àm. A falta de consciência reflexiva, isto é, a incapacidade de ouvir, entender e lembrar (kuma kêt, em que kêt é a partícula de negação), e a ausência da vergonha (pia'àm kêt) são fenômenos interligados, e ambos podem ser equacionados ao problema da indiferenciação e, consequentemente, da violência.

Os Xikrin dizem que uma pessoa excessivamente feroz ou tomada de fúria incontrolável é incapaz de ouvir os parentes (me inhõbikwa mari kêt). Ela perde a capacidade de entendimento e raciocínio. Nesses casos, tal pessoa é dita "surda" ("não escuta, é surdo", tradução da expressão a ma kre kêt $\approx$ que significa literalmente "sem ouvido"). Nesse estado, é como se seu corpo fosse um corpo não humano, como se a pessoa atingisse um estado de indiferenciação corporal absoluta: não sentindo dor, fome, sede, medo, piedade, compaixão, não mais se desviando dos obstáculos na mata, andando sempre em frente, em linha reta, atravessando cipoal, galhos, espinhos. Ela se torna então um grande perigo, um matador incapaz de discernir (o certo do errado, o parente de um não parente, o amigo de um inimigo etc.). A violência mais perigosa é o resultado de uma completa indiferenciação, ao mesmo tempo interna e externa.

Assim, no universo mebêngôkre não existe incompatibilidade entre o viver bem e os mecanismos de estruturação e diferenciação social. Muito pelo contrário, a estruturação diferenciante é a garantia mesma da possibilidade da boa vida. Por conseguinte, é a indiferenciação o problema de fundo. Esta é vista pelos Xikrin como inimiga do bem viver. Contra seus efeitos, os índios empreendem esforços simbólicos e práticos e engendram uma série de mecanismos de ordem ética, psicológica e sociológica. 
O tema da indiferenciação, que aqui evoco por meio do material xikrin e mebêngôkre, poderia, com toda certeza, ser analisado em termos comparativos e teóricos mais abrangentes. Evoquemos, por exemplo, a discussão de Lévi-Strauss sobre o tema dos gêmeos em Histoire de lynx (1991). Ali, após uma breve recensão das mitologias de gêmeos em diversas tradições culturais, Lévi-Strauss sugere que a simbologia indígena dos gêmeos jamais vindica uma identidade que não seja instável e provisória ("a identidade não pode durar", diz ele). Para Lévi-Strauss, isto sugere "que o pensamento ameríndio atribui à simetria um valor negativo, maléfico mesmo" (1991:305). Daí a famosa noção do "dualismo em perpétuo desequilíbrio" (1991:311) que, segundo o antropólogo francês, marcaria a filosofia social indígena, com reflexos na "ideologia" e na "organização social".

Lévi-Strauss restringiu-se à dimensão filosófica e sociológica do problema, e não abordou sua dimensão ética e existencial. O material xikrin, como venho tentando argumentar, permite iluminar este último aspecto. Podemos suspeitar que a simetria nada mais seja do que um símbolo da indiferenciação. Se adicionarmos ao argumento de Lévi-Strauss as hipóteses de Girard (1972) acerca das crises miméticas ou crises de indiferenciação, torna-se possível passar do plano lógico-cognitivo ao plano ético-existencial. Segundo Girard, o espelhamento dualista ou simétrico, do tipo apontado por Lévi-Strauss na passagem mencionada - espelhamento que é expresso pelas figuras de duplos e gêmeos, por exemplo — é uma representação transcultural contundente de crises de indiferenciação, ou seja, de situações epidêmicas, violentas e fortemente destrutivas (hipotéticas ou mesmo históricas) de mimese rivalitária. ${ }^{8} \mathrm{~A}$ simetria manifesta na simbologia gemelar é, no fim das contas, a expressão da dissolução completa das diferenças, não de um ponto de vista meramente lógico, mas concreto, tendo a dimensão de um problema existencial. Trata-se de um espelhamento infernal que só pode conduzir ao enfrentamento, à violência, à desordem, enfim, à morte individual e coletiva. Assim, não é apenas por uma questão cognitiva, teórica ou estética que os índios rejeitam a simetria gemelar, mas porque ela é o símbolo de tudo aquilo que os impede de viver bem.

Assim, em todos os níveis de análise, por trás de distintos planos de discurso, ações e ideias xikrin sobre o bem viver, um mesmo tema parece pulsar insistentemente, e este tema diz respeito ao problema da diferenciação. Para dizer de um modo um tanto brusco, o bem viver, no universo xikrin e mebêngôkre, está essencialmente vinculado ao sucesso ou ao fracasso da coletividade em evitar processos de indiferenciação, associados, no pensamento indígena, ao ciúme, às rivalidades, à violência e à morte. 


\section{Ritual e totemismo como mecanismos de diferenciação}

No plano das relações interpessoais, a indiferenciação - geradora de crises miméticas e violência, impeditivas do viver bem — é evitada por meio de instrumentos éticos ou morais, como as noções de vergonha, respeito e entendimento. Mas haveria também entre os Xikrin e Mebêngôkre procedimentos que visam garantir uma determinada estrutura relacional diferenciante em nível coletivo ou sociológico mais abrangente? Quais são eles? E qual a relação entre tais processos e a noção de propriedade entre os Mebêngôkre?

Quero sugerir que esses procedimentos compreendem fundamentalmente o domínio ritual. Por domínio ritual entendo não apenas o conjunto de performances, festas e ritos que compõem a vida cerimonial, mas também o sistema de repartição e transmissão de conjuntos de nomes, prerrogativas, direitos, regalias e objetos de valor (nêkrêjx ou kukràdjà), que foram descritos como "preciosidades" (valuables) por Turner (1991) e "riqueza" por Lea (1986). De fato, todos os grupos mebêngôkre possuem tradicionalmente conjuntos de bens simbólicos e cerimoniais que funcionam como signos distintivos de indivíduos ou grupos familiares. Nomes e nêkrêjx são propriedade ou direitos de determinadas pessoas e famílias e são transmitidos intergeracionalmente, na forma de herança, de indivíduo a indivíduo, por meio de uma regra fixa de relação entre determinados parentes "cruzados". Esse mecanismo de transmissão é muito bem documentado na etnografia, bastando aqui rememorá-lo rapidamente. Um menino recebe nomes e nêkrêjx de um ou mais parentes masculinos da categoria ngêt - que inclui as posições genealógicas MB, MF, FF etc. Uma menina recebe nomes e nêkrêjx de uma ou mais parentes do sexo feminino, da categoria kwatyj - que inclui FZ, MM, FM etc. Em relação a esses parentes, ego de ambos os sexos (isto é, o indivíduo que recebe a herança) está na categoria tàbdjwö.

O objetivo imediato das mais importantes cerimônias mebêngôkre é atribuir às crianças, publica e coletivamente, os bens cerimoniais herdados de seus parentes. Durante as performances, as crianças homenageadas exibem sua regalia na praça da aldeia e dançam junto com os nominadores que lhes transmitiram os bens. Com isso, torna-se público o fato de que, doravante, essas crianças também são legítimas donas desses bens, adquirindo, portanto, o direito de transmiti-los, elas mesmas, quando forem adultas, aos seus próprios sobrinhos e netos. Os rituais são, por conseguinte, o contexto propício para que a coletividade saiba "quem é quem" em termos de bens e itens de alto valor cultural. As festas são o momento em que as prerrogativas cerimoniais das crianças devem aparecer diante de todos, devem ser mostradas (o ami rint, em que ami é partícula reflexiva, e rint é um verbo 
com sentido de aparecer ou revelar). Findo o ritual, as crianças são tidas por pessoas sociais mais plenas, ou "belas", conforme a categorização indígena expressa na palavra mejx. Exatamente por isso, as crianças honradas durante os rituais denominam-se mereremejx, expressão que denota um sentido próximo de "aqueles a quem se dá/outorga a beleza", "aqueles que se tornam belos". Entre os Xikrin, as próprias performances rituais podem ser denominadas mereremejx.

Em síntese, os rituais fornecem o quadro social para que os objetos cerimoniais sejam visualizados e explicitados diante de toda a comunidade enquanto emblemas de determinadas pessoas e famílias. As performances rituais, elas mesmas, podem ser vistas como um ordenamento temporal e espacial de diferentes bens cerimoniais (Fisher 2003). De fato, a correta distribuição de conjuntos de adornos, papéis e cantos durante a festa - seu aparecimento no meio do pátio da aldeia em sequência correta, e na correta disposição ou posicionamento - indica harmonia, simetria e beleza. Num certo sentido, conforme mencionei anteriormente, é isso que faz a cerimônia ser bela e, em última instância, faz a própria coletividade ser bela, correta e completa. Não é por outra razão que os rituais mebêngêkre evocam sempre a imagem de uma totalidade social.

Foi a etnóloga Vanessa Lea (1986) quem pela primeira vez deu o devido destaque ao aspecto diferenciante dos bens cerimoniais entre os grupos mebêngôkre. Lea fez uma pesquisa detalhada sobre os conjuntos de nomes e prerrogativas e os descreveu como a riqueza ou a propriedade de unidades matrilineares que ela designou pelo termo "Casa" ou "Matricasa" (ver, p.ex., Lea 2012). Ela inspirava-se na noção de "société à maison" elaborada por Lévi-Strauss, embora tenha empregado o termo de forma diferente daquela do antropólogo francês, para quem o termo aplicava-se antes a sociedades cognáticas ou a sociedades sem um princípio exclusivo de descendência unilinear (ver Gordon 2006:369; Gordon 1996). Os meus próprios dados entre os Xikrin contradizem a ênfase de Lea na noção de Casa enquanto unidade matrilinear e parecem sugerir que deveríamos nos manter mais próximos da elaboração do conceito de maison por Lévi-Strauss, em que a propriedade cerimonial está vinculada a famílias cognáticas e pode ser transmitida estrategicamente, seja pelo lado materno, seja pelo lado paterno. Porém uma discussão pormenorizada deste ponto não é necessária para os objetivos deste artigo.

É preciso insistir, por outro lado, na importância fundamental da dimensão diferenciante do sistema, destacada por Lea. Em suas palavras: “Nomes e nekretx (sic) constituem a essência ancestral [...] que compõe a identidade distintiva de cada Casa" (Lea 2012:98). Mais do que isso. De acordo com as mulheres da aldeia Metyktire com quem Lea trabalhou: "Qualquer aldeia 
mêbêngokre específica é uma versão parcial de uma aldeia ideal onde a totalidade das matricasas forma um único círculo" (:121). Isto significa que o protótipo ideal de uma aldeia mêbêngokre é pensado, ao modo de um sistema estruturalista, como um conjunto finito de unidades diferenciadas e, portanto, diferenciantes, que se definem pela propriedade de determinados bens cerimoniais distintivos.

Esse sistema apresenta feições claramente totêmicas. Aqui é útil esclarecer de forma breve meu uso da noção de totemismo. Digo isso porque o clássico termo ganhou recentemente novo destaque antropológico na formulação de Philippe Descola (2005). Para este autor, o totemismo é visto primordialmente como um modo de identificação entre humanos e não humanos. Ele é uma das transformações dos quatro esquemas relacionais possíveis de objetificação da natureza — naturalismo, totemismo, animismo e analogismo - que, segundo Descola, se apoiam na percepção universal de uma dupla dimensão ontológica: intencionalidade (ou interioridade) e fisicalidade (ou corporalidade). De maneira bastante simplificada por mim aqui, o totemismo é, na versão de Descola, o modo de objetificação em que um mesmo tipo de fisicalidade e interioridade é considerado como particular a determinados conjuntos de seres humanos e não humanos, que se constituem, então, em grupos totêmicos específicos. Em suma, os grupos totêmicos são formados por seres humanos e não humanos que compartilham, nesta concepção, uma mesma fisicalidade e uma mesma interioridade.

Conquanto engenhoso e elegante, o modelo de Descola resulta na obliteração de um aspecto a meu ver fundamental de uma outra definição célebre do totemismo, dada por Lévi-Strauss (1962) há cerca de cinquenta anos. Como se sabe, Lévi-Strauss dissolveu o que qualificou de "ilusão totêmica" nos termos formais estruturalistas. Ele analisou o fenômeno enquanto um mecanismo lógico de diferenciação e classificação, que se obtinha por meio da projeção no eixo das relações sociais humanas de diferenças significativas percebidas no plano das espécies naturais. O totemismo era basicamente uma operação mental, um modo de relacionar séries de relações de diferenças. Embora considerasse as implicações sociológicas dessa operação - a saber, garantir a existência de unidades sociais básicas que pudessem engajar-se em trocas matrimoniais - Lévi-Strauss não percebeu uma função sociopolítica importantíssima do totemismo. Acredito que tal função permite situá-lo dento de um quadro mais vasto de interditos comuns às sociedades não modernas, tal como sugeriu Girard (2007:20). Este último autor parece-me convincente ao demonstrar que a função dos interditos, tais como os interditos totêmicos e outros interditos de natureza sexual, "seria a de repartir previamente todos os objetos desejáveis, de modo a prevenir as rivalidades miméticas". 
O argumento me parece importante. Ao estabelecer uma divisão prévia dos recursos simbólicos disponíveis e desejáveis, o totemismo não se limita a uma operação mental, ou a um jogo lógico e intelectual de diferenciação. Ao contrário, ele tem uma finalidade prática crucial e intrinsecamente associada à dimensão existencial e ao bem viver. Se Girard está certo, uma instituição tal como o totemismo visa impedir as rivalidades internas, a cobiça, as disputas por recursos simbólicos, ao efetivar sua repartição prévia, e conferir aos grupos ou unidades sociais relevantes uma forma de propriedade cujo caráter distintivo é relativamente estável e mais ou menos fixo. O totemismo forneceria, assim, um esquema global, cuja finalidade é análoga à ética das relações interpessoais, qual seja: evitar o desencadeamento de processos de indiferenciação e rivalidades miméticas no seio da comunidade.

Eis aí, nesse sistema de tipo totêmico, a possibilidade da existência de propriedades diferenciais capazes de se harmonizarem sistemicamente em um todo formado de partes distintas e complementares. Ora, isso me parece perfeitamente coerente com o sistema de bens cerimoniais mêbêngokre descrito por Vanessa Lea. Cada grupo (seja matricasa ou família cognática) dispõe, idealmente, de seu próprio acervo de nomes, bens e recursos, que podem ser, no máximo, trocados ou articulados uns aos outros por meio de procedimentos rituais e formais, e eventualmente, por aliança matrimonial, mas que devem, no fim das contas, permanecer distintos, como forma de impedir as disputas e os processos miméticos disruptivos.

Como não poderia deixar de ser, a fundamentação cosmológica ou "religiosa" desse sistema é estabelecida no plano mítico. Alguns conhecidos mitos de origem mebêngôkre narram o surgimento desse sistema de tipo totêmico. Por exemplo, o mito da Grande Ave Predadora (Àkti) explica o surgimento de toda a diversidade de pássaros e de todos os tipos de adorno plumário (nêkrêjx) que caracterizam as diferenças atuais. Outro exemplo é o mito da aquisição dos grandes nomes cerimoniais provenientes do mundo aquático (Lukesch 1968; Wilbert 1978; Lea 1986). Todas essas narrativas encaixam-se na famosa fórmula lévi-straussiana da "passagem do contínuo ao discreto", do indiferenciado ao diferenciado. Mas elas se encaixam também na fórmula girardiana do sacrifício. Girard pretendeu mostrar, precisamente, o modo como o sacrifício é capaz de realizar a passagem do indiferenciado ao diferenciado por meio de uma separação básica e estruturante: a oposição entre vítima e coletivo vitimário. O sacrifício instaura uma violência reparadora e estruturante (a violência de todos contra um), quando antes havia uma violência indistinta e indiferenciada (a violência de todos contra todos, típica das crises miméticas agudas).

Conforme bem observou Girard em dois artigos instigantes (1976, 1977), nos quais reanalisou alguns mitos estudados por Lévi-Strauss em Le tote- 
misme aujourd'hui (1962), a passagem do contínuo ao discreto se faz, nessas narrativas, invariavelmente ao modo de uma eliminação radical e violenta de um personagem por uma coletividade, uma espécie de imolação ou predação fundadora. $\mathrm{O}$ fato de que a passagem do indiferenciado ao diferenciado expressava-se sempre na forma de uma imolação foi rejeitado pela análise estrutural, que recodificou esse elemento narrativo crucial em termos de uma necessidade lógico-formal ou topológica: reduzir o excesso de significante, empobrecer o contínuo, criar espaços vazios para que o pensamento possa operar a significação. Lévi-Strauss tomou os personagens míticos apenas em sua dimensão geométrica ou topológica, como fragmentos anônimos que ocupam certa posição no espaço (Girard 2002:17), desprezando todo o seu conteúdo narrativo e dramático.

Mas no caso dos mitos mebêngôkre, por exemplo, o drama vitimário também está expresso claramente em vários mitos: ele ocorre pela destruição do grande Gavião Real e a criação dos adornos plumários; pelo ataque à sociedade dos Peixes e a captura dos grandes nomes cerimoniais; pelo assassinato da Mulher Jaguar e o roubo do fogo marcando a transição do cru ao cozido. A ordem cultural totêmica diferenciada instaura-se, portanto, na sequência de um tipo de imolação original — que a tradição etnológica tem glosado pelo termo "predação" (Viveiros de Castro 1993) - que já é, ela mesma, a instauração de uma primeira diferença fundante entre uma coletividade e uma vítima. ${ }^{9}$

Se os mitos falam desta instauração, os rituais fazem a mesma coisa no plano da ação, e promovem a rememoração do drama mítico que criou a diferenciação. Promovem-na por meio da reencenação dos eventos que teriam dado curso à passagem do indiferenciado ao diferenciado. Assim, o ritual, embora reencene a indiferenciação e o estado transformacional ou metamórfico, não o faz por nostalgia (conforme imaginou Lévi-Strauss), mas porque precisa reencenar também todos os momentos do processo que culminou com o fim do indiferenciado e a instauração da ordem cultural composta por diferenças de tipo totêmico. ${ }^{10}$ Por conseguinte, a metamorfose ritual, que poderíamos colocar no plano das indiferenciações, ou da representação do indiferenciado (e por isso nele se nota a presença de tantas figuras monstruosas, como máscaras, homens-pássaro, homens-jaguar), serve, em última instância, para reafirmar, no palco do processo social, as diferenças. Se a metamorfose ritual evoca a indiferenciação (entre homens e animais, entre mito e história etc.), esta só pode ser temporária e circunscrita a um contexto espaço-temporal controlado, cujo objetivo último é precisamente a reafirmação de uma diferenciação global entre todos esses termos, e de uma segmentação no seio da comunidade capaz de garantir que a vida não 
caia naquele estado limite da indiferenciação, ou pelo menos não se aproxime perigosamente dele, estado este que ameaça o bem viver no plano de coletividade inteira, e que não significa outra coisa, em última instância, do que a própria morte.

\section{História e crise do sistema ritual}

Até aqui vim descrevendo de que forma as noções de bem viver entre os Xikrin Mebêngôkre estão vinculadas a uma determinada ética indígena que parece ver na indiferenciação um símbolo de perigo, ameaça e morte, e propõe como resolução terapêutica sua eliminação pelo estabelecimento da diferenciação ao modo de um sistema estrutural. Tentei demonstrar que, no plano sociológico mais amplo, esta ética parece se realizar idealmente no estabelecimento de um sistema de propriedade de tipo totêmico, delimitando o domínio ritual e projetando a ideia da sociedade como uma totalidade formada de unidades distintas e complementares, relativamente estáveis e discretas, de maneira a impedir a eclosão das rivalidades e das disputas miméticas de tipo aquisitivo.

Porém, neste ponto as coisas se complexificam, uma vez que toda uma dimensão importante dos processos de diferenciação ritual, tratada por mim em outros trabalhos (Gordon 2006, 2010a, 2010b), ainda não foi mencionada neste artigo. Refiro-me a um outro tipo de diferenciação, que chamei de "hierárquica", igualmente presente no sistema ritual mebêngokre, mas que desenha uma paisagem muito mais dinâmica, como sói ser sempre que os esforços humanos de constituir o bem viver se defrontam com a história. Este modo de diferenciação caracteriza-se precisamente por seu caráter aquisitivo e por seu aspecto mimético, contrariando o modelo de tipo totêmico tal como descrito por Vanessa Lea.

Com efeito, as melhores etnografias dos grupos mebêngôkre sempre registraram um tipo de divisão interna de prestígio e valor social, expressa muitas vezes de modo explícito no discurso dos índios, entre pessoas ditas "bonitas" (me mejx) - detentoras de bens cerimoniais e de condições sociais e materiais capazes de garantir a realização de rituais - e pessoas ditas "comuns" (me kakrit), ou sem beleza, seja porque não possuíam um conjunto significativo de bens cerimoniais, seja porque não conseguiam arcar com os custos materiais da produção dos rituais.

A dimensão hierárquica da socialidade mebêngôkre já havia sido estudada por Terence Turner (1984), ainda que sua abordagem não tivesse focalizado uma economia política dos bens simbólicos, e sim uma "economia 
política de pessoas" (Gordon 2006, cap. 2). Turner descreveu a sociedade mebêngôkre como uma ordem política baseada em uma estrutura hierárquica de relações de exploração da produção social — ele sugeria uma exploração dos mais jovens pelos mais velhos e das mulheres pelos homens - gerando uma distribuição assimétrica de valor social (Turner 1991:2). Porém, a noção de uma assimetria baseada em bens cerimoniais já estava de alguma forma contida, em germe, na própria etnografia de Vanessa Lea (1986).

Eu mesmo apontei a ambivalência das conclusões desta autora (Gordon 2006:93). Mesmo sem ter tirado as devidas implicações dos dados por ela apresentados, Lea percebeu en passant, já no final de sua etnografia, que os bens cerimoniais não eram apenas emblemas das Casas, mas haviam se tornado uma fonte de prestígio para seus detentores (Lea 1986:341). Era exatamente por esta razão que sua etnografia falava tanto de disputas, roubos, e conflitos em torno dos nomes e nekrêjx, bem como da grande preocupação de famílias e indivíduos de não perder alguns de seus bens. Curiosamente, Lea falava também de bens cerimoniais que poderiam se desvalorizar em virtude da sua excessiva circulação, sendo desprezados pelos donos originais (por que alguém abandonaria um emblema distintivo da sua Casa?); ou, ao contrário, valorizar-se em função da sua raridade e exclusividade. Todo esse cenário de disputas, aquisições, muitas vezes agônicas e quase obsessivas, assim como um jogo complicado de valorização e desvalorização, de concentração e dispersão, já estava muito distante do modelo totêmico de repartição prévia e harmônica da propriedade cerimonial. Já estávamos no reino delicado do desejo mimético (Girard 1961).

Quando realizei minha pesquisa de campo com os Xikrin, embora não dispusesse das ferramentas conceituais proporcionadas pela teoria mimética, procurei extrair todas as consequências analíticas desse cenário. Parecia-me, claramente, que os aspectos totêmicos do sistema ritual descritos por Lea eram, àquela altura, menos visíveis ou menos operativos entre os próprios Metyktire (comunidade mebêngôkre em que Lea fez sua pesquisa) e em especial entre os Xikrin. Meu esforço então foi o de demonstrar a existência do componente hierárquico e fortemente rivalitário na sociedade mebêngôkre, que se expressava por meio do sistema cerimonial, mas também através de processos de incorporação de bens e objetos oriundos de outras sociedades, incluindo-se a sociedade não indígena, tais como as mercadorias e o dinheiro. A tônica do argumento era a de que havia entre os Xikrin uma busca por distintividade (Gordon 2006). Este modo de diferenciação hierárquica resultava na tentativa de magnificação de determinadas famílias e líderes políticos ou chefes, em termos de maior "beleza" e maior capacidade de agenciar objetos de valor provenientes do exterior, como mercadorias e dinheiro. A busca por distinti- 
vidade atrelava-se a um impulso aquisitivo, ou seja, passava pela tentativa de adquirir e concentrar recursos simbólicos, rituais, monetários etc.

Ao invés de repartir o campo da propriedade em elementos estáveis e fixos de maneira a evitar as rivalidades, o sistema que eu descrevi em Economia selvagem (2006) permitia o acúmulo, e gerava disputas miméticas incessantes não apenas no interior de cada comunidade ou aldeia, mas também entre elas, num jogo constante de indiferenciação e novas tentativas de diferenciação. No caso dos bens industriais, o consumo crescente que resultava desse jogo me levou a denominar a relação dos Xikrin com eles em termos de uma espécie de "inflação indígena" (Gordon 2010a). Creio ter sido capaz de explicar que tanto os bens e os valores provenientes do mundo dos brancos quanto os bens cerimoniais tradicionais funcionavam segundo uma mesma lógica: uma complexa economia política, uma busca por distintividade, cujo efeito não era mais o estabelecimento de diferenças esquistatutárias, e sim diferenças hierárquicas, de valor social, prestígio e poder - um cenário mais mimético (no sentido girardiano) do que totêmico. A análise histórica e comparativa entre as diversas aldeias mebêngôkre e os Xikrin me permitiu mostrar que esse processo estava operando provavelmente desde antes do contato definitivo dos índios com os brancos, e acabou impelindo os primeiros a intensificar as relações com estes últimos em busca de objetos capazes de funcionar como propriedade diferenciante.

Mas havia um aspecto paradoxal em todo esse processo. Inicialmente incorporados pelos Xikrin dentro do sistema de bens cerimoniais, os objetos provenientes do mundo dos brancos, tanto por sua qualidade quanto por sua quantidade, acabaram transbordando esse sistema. E mais do que isso, o incremento dos objetos industrializados na sociedade Xikrin, de maneira geral, veio a facilitar ou a democratizar o acesso às condições materiais de produção dos rituais. Em meio a um contexto mimético generalizado, isto teve o efeito de acelerar todo o mecanismo ritual, posto que muito mais pessoas puderam realizar as cerimônias de confirmação ritual, o que resultou em uma espécie de vulgarização da "beleza cerimonial", e concorreu para o progressivo apagamento do rendimento sociológico da própria distinção entre "belos" e "comuns". Com isso, surgiu uma espécie de consumo diferencial (ou consumo "de luxo") de bens industrializados, como um mecanismo substitutivo de produzir a diferenciação hierárquica. A diferença entre "ricos" e "pobres" tornara-se mais presente no discurso xikrin do que a diferença entre "belos e comuns". Sem dúvida, a primeira era uma transformação da segunda. Mas a transformação tinha efeitos no sistema como um todo.

O que estava por trás do consumo inflacionário era, no fim das contas, um processo em que o ritual, apesar de cada vez mais acionado (e por esta mesma razão), mostrava-se cada vez menos apto a diferenciar. Eu sugeri 
que, naquela altura, havia um esgotamento do sistema ritual para produzir as diferenças, não só de tipo totêmico, mas também de tipo hierárquico. E que estas últimas haviam se deslocado para um campo extrarritual, ou que nós chamaríamos de econômico, ainda que suas raízes fossem o domínio ritual. Ocorre que, fora do sistema ritual, o consumo distintivo e a riqueza estavam ainda mais facilmente sujeitos às pressões miméticas, adquirindo assim uma dimensão incremental, evocando, em termos caricatos, uma corrida de gato e rato. Os chefes e as famílias importantes (gente tradicionalmente "bonita") procuravam apropriar-se de mais bens industrializados e dinheiro, e os não chefes imitavam-nos, pressionando pela comunização, o que premia os chefes a procurar novos nichos de consumo cada vez mais exclusivos e quantidades de dinheiro, e assim sucessivamente.

Havia ali, portanto, todos os sintomas de uma crise de indiferenciação, uma crise do ritual, a qual os Xikrin procuravam resolver pela absorção cada vez mais rápida, e em quantidades cada vez maiores, de recursos provenientes do exterior. A escalada mimética e a busca agônica por distintividade requeriam doses cada vez maiores de objetos extrarrituais: mercadorias, bens industrializados e dinheiro. Esta me parecia a razão da natureza inflacionária do consumo xikrin.

Naquela ocasião, diante desse cenário, cabia perguntar-lhes diretamente sobre o bem viver. Teria ele se transformado, no fim das contas, nessa corrida acelerada ao consumo, cujo efeito era uma expansão do impulso mimético de dentro para fora? Afinal, um modo radical de criar a diferença interna é assemelhar-se cada vez mais aos brancos (mas com isso reduzindo a diferença externa). De qualquer modo, os Xikrin não tinham ainda uma resposta inequívoca sobre o que estava a ocorrer. Mas, certamente, ainda que alguns considerassem os benefícios de uma vida mais parecida com a dos brancos, que muitas vezes parecem fazer a figura do modelo a ser imitado, havia um indisfarçável mal-estar que me foi dado a notar. Ele era expresso de maneira um tanto oblíqua pelo temor de "virar branco". Era como se os Xikrin tivessem intuitivamente percebido que à custa de diferenciarem-se um dos outros, acabaram caindo, paradoxalmente, no labirinto mimético, colocando em risco de fracasso seu modelo de bem viver.

Caminhando para a conclusão, valeria a pena questionar mais a fundo este gigantesco descompasso de um sistema voltado à produção da diferenciação tornar-se incapaz de fazê-lo, resultando, contraditoriamente, em uma situação de crescente indiferenciação. Não havia mais um mecanismo diferenciante totêmico-ritual plenamente operativo, de sorte que a dimensão hierárquica e rivalitária do sistema, desdobrando-se na história, permitiu a irrupção de algo muito próximo de uma crise mimética na sociedade xikrin e mebêngôkre. 
Mas qual seria, afinal, a natureza do sistema totêmico que lemos na etnografia de Vanessa Lea e que parece tão consistente com as noções xikrin de bem viver que discuti nas primeiras partes deste texto? Teria Lea descrito o sistema de Casas ou matricasas com base em uma perspectiva puramente normativa? Teriam as mulheres metyktire relatado a Lea um modelo ideal do que deveria ser, e não do que efetivamente se passava na vida real? Estas são perguntas que não tenho como responder decisivamente nesta altura. Porém, como exercício intelectual, creio ser cabível aventar uma hipótese. Uma hipótese de cunho histórico.

Talvez a progressiva crise de indiferenciação que acometeu os Mebêngôkre como um todo, e se mostrou de forma aguda entre os Xikrin, possa ser explicada se postularmos a existência histórica de um amplo sistema totêmico, mas que teria entrado em colapso em algum momento da história mebêngôkre, resultando no aparecimento de um sistema ritual "imperfeito", por assim dizer, posto que permitia o acúmulo de propriedade e a consequente transformação dos emblemas totêmicos em "fonte de prestígio" e riqueza. É possível supor que no momento em que os grupos mebêngôkre foram pela primeira vez contatados, na segunda metade do século XIX, esse sistema já estivesse entrando em decadência, e que, na época em que os antropólogos começaram a realizar suas pesquisas com esses grupos, nos anos 1960, dele restassem apenas fragmentos parciais na forma dos conjuntos de nomes e prerrogativas, tais como registrados por Lea.

É possível também supor que esses conjuntos de bens cerimoniais tenham constituído no passado um sistema totêmico mais geral de repartição global de todos os recursos materiais e simbólicos, provavelmente associado a trocas matrimoniais, capaz de sustentar a existência de aldeias maiores e mais densamente povoadas, às quais os Mebêngôkre muitas vezes fazem menção de terem existido no passado. É verdade que nenhum antropólogo o descreveu, e quem chegou mais perto disso foi Vanessa Lea, como vimos. Mas há alguns indícios de que, eventualmente, a retomada de extensas pesquisas históricas e comparativas com os diversos grupos da família linguística Jê possa confirmar. Não custa lembrar de forma breve a hipótese de Nimuendaju (1946:90) sobre os grupos de praça Timbira, que eram sociedades cerimoniais do mesmo tipo que certas sociedades cerimoniais existentes entre os Mebêngôkre. Para Nimuendaju, esses grupos corresponderiam a uma antiga organização clânica que teria perdido a regularidade genealógica.

Um outro indício, embora tênue, é a existência de certos nomes antigos mebêngôkre, atualmente pouco usados, ou que aparecem apenas em personagens míticos, mas que correspondem exatamente aos nomes das metades sazonais Timbira. Por exemplo: os nomes mebêngôkre Wakme 
(não mais em uso e só referido em narrativas míticas) e Kàtàm (ainda em uso, mas muito raro) correspondem fielmente às metades sazonais Timbira Wakmejê e Katamjê. As categorias de nomes Bep, Katám, Wakme, Tàkàk poderiam, então, ser nomes totêmicos ao modo australiano, uma vez que eles se subdividem de acordo com partes de animais correspondentes (ver Lea 1986, para uma descrição detalhada dos nomes mebêngôkre). Alguns xikrin diziam que a pessoa com o nome de uma parte de animal ou planta possuía, no passado, o direito de propriedade e gozo relativo da parte do animal ou da planta indicada em seu nome.

Não se pode desconsiderar também o impacto das frentes de expansão colonial no território historicamente ocupado pelos Mebêngôkre, processo que resultou em perdas demográficas consideráveis, implicando, ademais, sucessivas mudanças territoriais, decomposição e recomposição de aldeias, separações, maior isolamento etc. As retrospectivas históricas de Verswijver (1992) e de Fisher (2000) são exemplares em mostrar a enorme mobilidade e a complexidade das decomposições e recomposições das aldeias mebêngôkre desde meados do século XIX até o período da pacificação. Enfim, toda uma série de descontinuidades importantes pode ter concorrido para o colapso do sistema, na medida em que se alteraram consideravelmente as condições de reprodução social. Desmoronando, o sistema totêmico teria fornecido a ocasião para que alguns indivíduos se tornassem uma espécie de repositórios de conhecimentos, acumulando bens cerimoniais que de outra forma, na falta de condições ideais de transmissão, teriam se perdido. Mas na tentativa de salvá-los, podem ter introduzido uma nova lógica apropriativa e cumulativa. As divisões e as dispersões aldeãs teriam permitido também que os bens totêmicos pudessem transferir-se de uma família para outra por meio de estratégias e negociações ad hoc.

A nova situação teria aberto a possibilidade de magnificação pessoal, por meio da propriedade ou do controle de recursos simbólicos e materiais cobiçados, e da própria necessidade de lideranças firmes e valentes em tempos conturbados. Os bens cerimoniais, mesmo sendo transmitidos segundo uma regra de parentesco fixa, passaram a ser acumulados e disputados, visto que haviam perdido, em última instância, suas referências totêmicas inequívocas. Finalmente, as novas condições teriam liberado os mecanismos miméticos e rivalitários, cujo efeito foi visto desde o final do século XIX, na progressiva segmentação da sociedade, na proliferação de aldeias e no conhecido faccionalismo mebêngôkre. As constantes cisões que se seguiram, sempre em virtude de rivalidades internas, do aumento das acusações de feitiçaria, das disputas por mulheres, e a busca de grandeza, prestígio ou beleza geraram inimizades mútuas e guerras intestinas, tão marcantes na história recente desses grupos. 
Tal hipótese tem o benefício de explicar o aspecto centrífugo da dinâmica social mebêngôkre nos últimos cem anos, ainda em outro sentido. Pois diante da falência de um sistema de repartição totêmica cujo objetivo é fixar a propriedade dos recursos desejáveis e impedir a eclosão da mimese apropriativa, uma solução possível é a de multiplicar a gama de objetos desejáveis, reduzindo, assim, os efeitos perniciosos da inveja e das disputas. Talvez não tenha sido por outro motivo que, desde meados do século XIX, os grupos mebêngôkre tenham se lançado ao encalço de outros povos indígenas e dos brancos, na tentativa de incrementar seu acervo de bens culturais. Em suma, o colapso do sistema totêmico de diferenciação explicaria de uma só vez as duas grandes linhas de ação histórica dos Mebêngôkre até o período imediatamente anterior à pacificação: de um lado, o aumento das guerras internas (isto é, entre grupos mebêngôkre), por causa da eclosão das rivalidades miméticas e das crises de indiferenciação, que resultavam, repito, em inveja, cobiça, conflito por mulheres, acusações de feitiçaria etc.; de outro, o aumento dos contatos externos, quase sempre bélicos, com outros grupos indígenas e com os brancos, na busca desesperada por multiplicar os objetos desejáveis, como forma de aliviar a dinâmica mimética interna.

O processo de pacificação parece ter atenuado os conflitos, e não é de estranhar que isto tenha se dado pela promessa dos órgãos indigenistas brasileiros de promover uma multiplicação quase milagrosa de objetos. Se, por um lado, isto resolveu temporariamente os conflitos externos, por outro, não foi suficiente para aplacar totalmente as rivalidades internas, que persistiram, embora em uma chave menos violenta. Os Mebêngôkre logo começariam a perceber que existiam outros meios mais eficazes de operar no mundo dos brancos, como através da política e da economia. Mas isso já é outra parte da história.

De todo modo, devemos concluir, e não precisamos levar muito adiante nossas conjecturas. Independentemente de ter existido na história ou apenas na imaginação moral dos Mebêngôkre, o fato é que a ausência de um efetivo sistema de tipo totêmico parece ter tornado mais distante seu ideal de bem viver. Pelo menos por algum tempo. Pois a história está aberta ao futuro, e cabe aos Mebêngôkre encontrar novos modos de vida boa e bela.

Recebido em 17 de abril de 2013

Aprovado em 16 de setembro de 2013

Cesar Gordon é professor do Programa de Pós-Graduação em Sociologia e Antropologia, IFCS/UFRJ. E-mail: <cesar@cesargordon.net> 


\section{Notas}

* Uma primeira versão deste texto foi apresentada no Seminário (Im)proper relations: ownership and wellbeing in Amazonia, ocorrido em abril de 2010, no Museu Nacional da UFRJ, Rio de Janeiro, coordenado por Carlos Fausto, Marc Brightman e Vanessa Grotti. Agradeço a eles pelo convite e pelos comentários generosos que muito ajudaram a aperfeiçoar o texto. Agradeço ainda pelos comentários de Aparecida Vilaça, Marcela Coelho de Souza, Oiara Bonilla, Susana Viegas, Fernando Santos-Granero, e Pedro Niemeyer Cesarino. Carlos Fausto e Luiz Costa fizeram uma leitura atenta e generosa do texto original, contribuindo diretamente para sua forma final. Quaisquer erros reparados no artigo permanecem sendo de minha exclusiva responsabilidade.

${ }^{1}$ Neste artigo não se faz uma discussão teórica, desde a perspectiva da antropologia, do conceito de propriedade, bem como dos limites de sua aplicação transcultural. Sobre o assunto, veja-se, por exemplo, Hann $(1998,2007)$ e von Benda-Beckman (2006). O uso que faço do termo neste artigo é o uso lexicalizado trivial: bens sobre os quais se exerce algum direito de posse, usufruto ou transferência. Veja-se, no entanto, Gordon (2006) para uma análise mais pormenorizada das equivalências e diferenças entre as categorias mebêngôkre nêkrêjx e kukràdjà e a noção de propriedade.

${ }^{2}$ Para isso, veja-se Jimenez (2007); Matthews \& Izquierdo (2009).

${ }^{3}$ A suposta rejeição indígena à sociologia (Overing \& Passes 2000:1), isto é, a normas e a divisões internas, enfim, a "estruturas", não deixa de evocar, por analogia, outra célebre visão romântica das sociedades ameríndias, a saber, a de Pierre Clastres (1974), para quem a filosofia social indígena seria teleologicamente avessa ao Estado. A diferença é que se para Clastres, como bom herdeiro da tradição francesa, a sociedade aparece como a instância totalizante (é ela a causa final, que se opõe e barra a emergência do Estado), para Overing, nem isso mais existe: a sociedade não é uma entidade transcendente ou englobante, e a coletividade só emerge como produto da interação intersubjetiva de "sujeitos autônomos" ("autonomous selves"). Entendo que seria interessante investigar mais detidamente as semelhanças e as diferenças entre estes dois modelos fortemente ideológicos de descrição das sociedades indígenas - Clastres e Overing — bem como sua profunda inserção em duas modalidades nacionais - a francesa e a britânica — de pensamento social (veja-se Himmelfarb 2005). Mas certamente isso escapa aos limites deste artigo.

${ }^{4}$ Apesar de os termos Mebêngôkre e Kayapó serem tratados indiferenciadamente na literatura antropológica, eu os tenho utilizado da seguinte forma: o primeiro termo indica genericamente os grupos falantes da mesma língua e que compõem esse universo sociocultural mebengokre mais amplo, incluindo-se os Xikrin e todos os demais subgrupos kayapó; o segundo denota qualquer grupo mebêngôkre que não seja identificado como xikrin, por exemplo, os Kayapó-Gorotire, Kubenkrãkenh, Mekrãnoti ou Metyktire. Uma convenção adicional: desde meados da década de 1920, os Xikrin encontram-se divididos em dois blocos, denominados Xikrin do Ca- 
teté e Xikrin do Bacajá, em referência aos rios próximos do lugar onde construíram suas aldeias. Por simplificação, venho utilizando o termo Xikrin referindo-me, em princípio, aos Xikrin do Cateté, onde minha pesquisa foi realizada, salvo quando anotado em contrário.

${ }^{5}$ Os mebêngôkre também se envolveram em guerras "externas", isto é, contra populações distintas linguística e culturamente, fossem outros povos indígenas, fossem não indígenas. Gustaaf Verswjiver mostra de maneira acurada como as guerras internas e externas podem ser vistas como modalidades diferentes, envolvendo objetivos e métodos distintos. Para uma visão mais completa do belicismo mebêngôkre, veja-se Verswjiver (1992). Para um excelente relato histórico sobre os Xikrin, especialmente sobre o grupo do Bacajá, veja-se Fisher (2000).

${ }^{6}$ A frase em língua mebêngôkre me foi dita como krabipo ne kam mejx kêt (onde kabipo $\approx$ gêmeo; $n e \approx$ partícula "estativa"; kam $\approx$ preposição; mejx $\approx$ "bom"; kêt $\approx$ negativa) ou krabipo kam punure ("gêmeos resulta em coisa ruim"). Sobre a associação com os animais, alguns xikrin afirmaram que uma mulher grávida não deve assistir ao acasalamento de um casal de cães, pois isso aumentaria as chances de que ela própria gerasse gêmeos em uma gravidez futura. Alguns mitos de origem dos brancos e dos índios juruna (Yudja) os descrevem como filhos gêmeos múltiplos de uma mulher que copulou com uma cobra, com um lagarto, ou lagarta, a depender das diferentes versões da narrativa (Wilbert 1978:152-154; Turner 1988:205).

${ }^{7}$ Prossegue Coelho de Souza (2002:501-2): “Os Kayapó se referem explicitamente ao piààm [sic] entre casas dos homens como contribuindo para a paz da comunidade, uma vantagem das aldeias com duas casas dos homens (Turner 1966:43-4)". Por outro lado, uma vez que esta paz seja rompida, e as disputas cheguem a ponto de eclodir num enfrentamento físico, sob a forma ritualizada dos duelos formais que podem envolver toda a comunidade, o efeito do piaam [sic] é exigir uma separação ainda mais drástica das partes envolvidas: “Os Kayapó dizem que os derrotados vão embora porque sentem muita vergonha (piaàm) de permanecer na mesma aldeia junto com as pessoas que os venceram na luta" (Bamberger 1979:139).

${ }^{8}$ Veja-se em especial a discussão que este autor faz, nos capítulos II e III (1972:349-403), acerca da simetria, da indiferenciação e do espelhamento dos personagens das tragédias gregas.

${ }^{9}$ Um conjunto de questões que me pareceria interessante aproximar da presente discussão foi explorado recentemente por Fausto (2008), em artigo em que discute as noções de "dono" e "maestria" na Amazônia indígena. A ideia de "magnificação", por exemplo, sugere também, ainda que por outras vias, uma tensão entre processos de diferenciação e indiferenciação. Fausto argumenta de modo interessante (2008:334) que a pessoa magnificada de um chefe ou de um mestre projeta simultaneamente duas figuras sociais: de um lado, uma entidade de tipo mitológico ou "monstruoso" (um incorporador de diferenças, por assim dizer, e cuja magnificação é precisamente a expressão dessa condensação), e que se apresenta como singularidade; e de ou- 
tro, o bando, que se apresenta como coletivo indiferenciado que a ele se contrapõe. É curioso notar que estas duas figuras - o coletivo indiferenciado e (supostamente) passivo, e o dono enquanto singularidade magnificada - são análogas às figuras do esquema sacrificial tal como postulado por Girard (1972), ainda que em sentido inverso: para este último, é a coletividade que toma a forma ativa de agente sacrificador, enquanto a figura singular aparecerá inicialmente em seu caráter de monstro (indiferenciação interna a si mesmo) e, finalmente, como vítima do ato sacrificial.

${ }^{10}$ No final das Mitológicas (L'homme nu, 1971), Lévi-Strauss faz, de maneira sutil, uma de suas raras críticas valorativas ao pensamento indígena; crítica, quiçá, análoga à que ele fazia à própria filosofia francesa, e em especial à metafísica de Henri Bergson. A crítica aparece embutida na famosa distinção entre rito e mito. Este último, para Lévi-Strauss, encarnava um princípio de diferenciação, idêntico na linguagem e no pensamento, estando na base de toda simbolização. Já o ritual, para o antropólogo francês, expressaria uma tentativa de restabelecer uma imediação indiferenciada entre o homem e o mundo, desfazendo assim a obra da linguagem. No afã de afastar todo o espectro religioso, místico e metafísico da análise antropológica estruturalista, e de exaltar a linguagem, Lévi-Strauss acabou recaindo no dualismo bergsoniano, mas pela sua outra ponta e, assim fazendo, não pôde perceber nem todas as propriedades do rito, nem todas as propriedades do mito. Lévi-Strauss assimilou tudo o que não era linguagem ao cerne do comportamento ritual-religioso, escanteando o rito do âmbito do interesse da análise estruturalista. Paralelamente, mesmo reconhecendo as representações míticas do indiferenciado que insistiam em pulsar, Lévi-Strauss se esforçou por purificar o mito, postulando-o como o próprio processo de simbolização tornado visível. Fazendo uma pequena caricatura do dualismo lévi-straussiano, é como se o mito fosse o herói porque é capaz de desfazer a dose de indiferenciado inicialmente presente a título de representação do real (e assim o mito é uma espécie de espelho do pensamento humano em operação no seu afã de criar o inteligível); já o rito, este é o vilão, porque procederia de maneira inversa, juntando as figuras previamente separadas pela linguagem para produzir monstros indiferenciados, em sua nostalgia de reconexão, ou de re-ligação, com a realidade. Creio que as observações de Girard $(1976,1977)$, ao postular que tanto o rito quanto o mito fazem a mesma coisa, expressando ambos, a eliminação do indiferenciado, permitem-nos escapar do dualismo e do paradoxo lévi-straussiano. 


\section{Referências bibliográficas}

BAMBERGER, Joan. 1979. "Exit and voice in Central Brazil: the politics of fight in Kayapó Society". In: D. MayburyLewis (org.), Dialectical societies: the Gê and Bororo of Central Brazil. Cambridge, Mass. \& London: Harvard University Press. pp. 130-146.

BATESON, Gregory. 1958. Naven. 2. ed. Stanford: Stanford University Press. BELAÚNDE, Luísa E. 2001. Viviendo bien: gênero y fertilidad entre los Airo-Pai de la Amazônia Peruana. Lima: Centro Amazônico de Antropologia y Aplicación Práctica/BCRP.

CANTO, V. 1985. "Property rights, land reform, and economic well-being". Cato Journal, 5(1):51-66.

CLASTRES, Pierre. 1974. La société contre l'état. Paris: Minuit.

COELHO DE SOUZA, Marcela. 2002. O traço e o círculo: o conceito de parentesco entre os Jê e seus antropólogos. Tese de doutorado, PPGAS-Museu Nacional, UFRJ.

DESCOLA, Philippe. 2005. Par-delà nature et culture. Paris: Éditions Gallimard.

FAUSTO, Carlos. 2001. Inimigos fiéis: história, guerra e xamanismo na Amazônia. São Paulo: Edusp.

- 2008. "Donos demais: maestria e domínio na Amazônia". Mana. Estudos de Antropologia Cultural, 14(2):329-366.

FISHER, William. 2000. Rainforest exchanges: industry and community on an amazonian frontier. Washington: Smithsonian Institution Press. . 2003. "Name rituals and acts of feeling among the Kayapo (Mebengokre)". Journal of the Royal Anthropological Institute, 9(1):117-135.

FRANCHETTO, Bruna \& HECKENBERGER, Michael (orgs.). 2001. Os povos do Alto Xingu: história e cultura. Rio de Janeiro: Editora UFRJ.
FREY, B. 2002. Happiness and economics: how the economy and institutions affect human well-being. Princeton: Princeton University Press.

GIRARD, René. 2007a [1961]. Mensonge romantique et verité romanesque. Republicado em De la violenca à la divinité. Paris: Éditions Grasset. - 2007b [1972]. La violence et le sacré. Republicado em De la violenca à la divinité. Paris: Éditions Grasset. . 1976. "Differentiation and undifferentiation in Lévi-Strauss and current critical theory". Contemporary Literature, XVII(3):404-429. . 1977. "Violence and representation in the mythical text". MLN, 92(5):922944. Disponível em: http://www.jstor. org/stable/2906884. - 2002. La voix méconnue du reel. Paris: Édtions Grasset \& Fasquelle.

GORDON, Cesar. 1996. "Resenha de Carsten, J. \& Hugh-Jones, S. (eds.). About the house: Lévi-Strauss and beyond". Mana. Estudos de Antropologia Social, 2(2):192-195.

- 2006. Economia selvagem: ritual e mercadoria entre os índios Xikrin (Mebêngôkre). São Paulo: Edunesp/ ISA/ NuTI.

. 2010a. "L'inflation à la mode kayapo: rituel, marchandise et monnaie chez les Xikrin de l'Amazonie brésilienne". Journal de la Société des Américanistes, 96(2):205-228.

. 2010b. "The objects of the whites: commodities and consumerism among the Xikrin-Kayapo (Mebengokre) of Amazonia". Tipití: Journal of the Society for the Anthropology of Lowland South America, 8(2):1-22. . 2011. "Em nome do belo: o valor das coisas xikrin-mebêngôkre". In: C. Gordon 
\& F. A. Silva (orgs.), Xikrin: uma coleção etnográfica. São Paulo: Edusp. pp. 207-262.

- s/d. "Ferocidade e domesticidade: fundamentos da violência entre os índios Kayapó-Mebêngokre". Manuscrito não publicado.

GROTTI, Vanessa. 2007. Nurturing the other: wellbeing, social body \& transformability in northeastern amazonia. Ph.D. Thesis, University of Cambridge.

HANN, Chris M. (org). 1998. Property relations: renewing the anthropological tradition. Cambridge: Cambridge University Press.

. 2007. "A new double movement? Anthropological perspectives on property in the age of neoliberalism". Socio-Economic Review, 5:287-318.

HIMMELFARB, Gertrud. 2005. The roads to modernity: the British, French and American enlinghtments. New York: Vintage Books.

HUGH-JONES, Stephen. 1993. "Clear descent or ambiguous houses: a reexamination of Tukanoan social organisation". L'Homme (La remontée de l'Amazonie), XXXIII(126-128):95-120.

JIMENEZ, A. C. 2007. Culture and wellbeing: anthropological approaches to freedom and political ethics. London: Pluto Press.

KNIGHT, F. H. 1971. Risk, uncertainty and profit. Chicago: University of Chicago Press.

LASMAR, Cristiane. 2002. De volta ao lago de leite: gênero e transformação no Alto Rio Negro. São Paulo: Edunesp/ ISA/ NuTI.

LEA, Vanessa. 1986. Nomes e nekrets kayapó: uma concepção de riqueza. Tese de doutorado, PPGAS-Museu Nacional, Universidade Federal do Rio de Janeiro. - 2012. Riquezas intangíveis de pessoas partíveis. São Paulo: Edusp.
LÉVI-STRAUSS, Claude. 1962. Le totemisme aujourd'hui. Paris: PUF. . 1981 [1971]. The naked man. Mythologiques, v. 4. Chicago: University of Chicago Press. - 1991. Histoire de lynx. Paris: Plon.

LUKESCH, A. 1976 [1968]. Mito e vida dos índios caiapós. São Paulo: Pioneira/ Edusp.

MATTHEWS, G. \& IZQUIERDO, C. 2009. Pursuits of happiness: well-being in anthropological perspective. Oxford \& New York: Berghahn Books.

MAYBURY-LEWS, David (org.). 1979. Dialectical societies: the Gê and Bororo of Central Brazil. Cambridge, Mass. \& London: Harvard University Press. MILlER, Daniel. 1987. Material culture and mass consumption. Oxford: Basil Blackwell.

NIMUENDAJU, Curt. 1946. The eastern Timbira. Berkley: University of California Press.

NORTON, S. W. 1998. "Poverty, property rights, and human well-being: a cross-national study". Cato Journal, 18(2):233-245.

OVERING, J. \& PASSES, A. 2000. "Introduction: conviviality and the opening of Amazonian anthropology". In: J. Overing \& A. Passes (orgs.), The anthropology of love and anger: the aesthetics of conviviality in Native Amazonia. London \& New York: Routledge. pp. 1-30.

TURNER, Terence. 1966. Social structure and political organization among the northern Kayapó. Ph. D. Thesis, Harvard University.

. 1984. "Dual opposition, hierarchy and value: moiety structure and symbolic polarity in Central Brazil and elsewhere". In: J. C. Galey (org.), Différences, valeurs, hiérarchies: textes offerts à Louis Dumont. Paris: École des Hautes Études en Sciences Sociales. pp. 335-370. 
. 1988. "History, myth, and social consciousness among the Kayapó of Central Brazil". In: J. Hill (org.), Rethinking history and myth: indigenous South American perspectives on the past. Urbana: University of Illinois Press. pp. 195-213.

. 1991. "The Mebengokre Kayapo: hierarchy, social consciousess and social change from autonomous communities to inter-ethinc systems". Manuscrito inédito, cedido gentilmente pelo autor. . 1996. "Social complexity and recursive hierarchy in indigenous South American societies". Journal of the Steward Anthropological Society, 24(1-2):37-59.

VERSWIJVER, Gustaaf. 1992. The clubfighters of the Amazon: warfare among the Kayapo indians of Central Brazil. Gent: Rijksuniversiteit te Gent.

VIDAL, Lux. 1977. Morte e vida de uma sociedade indígena brasileira. São Paulo: Hucitec/ Edusp.

VIVEIROS DE CASTRO, Eduardo. 1993. "Alguns aspectos da afinidade no dravidianato amazônico". In: M. Carneiro da Cunha \& E. Viveiros de Castro (orgs.), Amazônia: etnologia e história indígena. São Paulo: NHIIUSP/ Fapesp. pp. 149-210.

_. 1996. "Images of nature and society in Amazonian ethnology". Annual Review of Anthropology, 25:179-200. · 2000. "Atualização e contraefetuação do virtual: o processo do parentesco". In: A inconstância da alma selvagem. São Paulo: Cosac \& Naify. pp. 403-455. VON BENDA-BECKMAN, F; VON BENDABECKMAN, K. \& WILBER, M. (orgs). 2006. Changing properties of property. Oxford: Berghahn.

WILBERT, Johannes (org.). 1978. Folk literature of the Gê Indians. Los Angeles: UCLA/ Latin America Center Publications. 


\section{Resumo}

O presente artigo é uma tentativa de refletir sobre propriedade e bem viver entre os índios Xikrin Mebêngôkre (Kayapó). Sustenta-se que tais noções devem ser articuladas com um problema indígena filosófico e existencial de magnitude: a diferenciação. Propõe-se que uma das definições do viver bem no mundo social mebêngôkre é manter, em todos os níveis da vida, um determinado quociente de diferença. Esta, por sua vez, vincula-se à questão da propriedade (em especial a propriedade cerimonial), uma vez que o sistema ritual deve ser visto como o mecanismo básico, em nível coletivo, de diferenciação. O estabelecimento de um sistema de repartição de propriedade de tipo totêmico serviria para evitar crises de indiferenciação e, portanto, garantir o bem viver. Sugere-se que o sistema ritual mebêngôkre passou por mudanças históricas importantes que deslocaram um tipo de diferenciação totêmica na direção de um tipo de diferenciação hierárquica, na qual há margem para o desenvolvimento de relações rivalitárias no interior das comunidades e entre elas.
The article reflects on property and wellbeing among the Xikrin-mebêngôkre (Kayapó) Indians. It argues that these notions must be articulated with a wider problem in Indigenous philosophy and existence: differentiation. It proposes that one of the definitions of well-being in the Mebêngôkre social world is the maintenance, in all levels, of a certain coefficient of difference. Difference, in turn, is linked to the notion of property (particularly ceremonial property), since the ritual system is a basic, collective mechanism of differentiation. The establishment of a totemic-type system of dividing property served to avoid crises of indifferentiation, thereby ensuring well-being. It is suggested that the Mebêngôkre ritual system underwent important historical changes that have shifted a totemic-type differentiation towards a hierarchical-type differentiation, within which rivalries can emerge both in the heart of communities and between them. Key words Amazonia, Property, Wellbeing, Differentiation, Ritual.

Palavras-chave Amazônia, Propriedade, Bem-viver, Diferenciação, Ritual. 